\title{
6. RefERENGES
}

DYER, A. F. 1964. Heterochromatin in American and Japanese species of Trillium. Cytologia, 29, 171-190.

John, B., AND HEwItT, G. M. 1966. Karyotype stability and DNA variability in the Acrididae. Chromosoma, 20, 165-172.

JONES, R. NEIL, AND REES, H. 1968. Influence of $B$-chromosomes in rye upon the nuclear phenotype. In press.

KEYL, H. G. 1964. Verdopplung des DNA Gehalte kleiner Chromosomen Abschnitte als Faktor der Evolution. Naturwissenschaften, 51, 46-47.

KEYL, H. G. 1965. A demonstrable local and geometric increase in the chromosomal DNA of Chironomus. Experientia, 21, 191.

LIMA DE FARIA, A. 1959. Differential uptake of initiated thymidine into hetero- and euchromatin in Melanopus and Secale. 7. Biophys. Biochem. Cytology, 6, 457-466.

MARTIN, P. G. 1966. Variations in the amounts of nucleic acids in the cells of different species of higher plants. Exp. Cell Res., 44, 84-94.

MGLEISH, J., AND SUNDERLAND, N. 1961. Measurements of deoxyribonucleic acid (DNA) in higher plants by Feulgen photometry and chemical methods. Exp. Cell Res., 24, 527-540.

мIтTwосн, U. 1968. Scope and limitations of feulgen microdensitometry. Chromosomes today. (In press.)

NiRULA, s., BHASKARAN, s., AND swaminathaN, M. s. 1961. Effect of linear differentiation of chromosomes on the proportionality between chromosome length and DNA content. Exp. Cell Res., 24, 160-162.

rees, h., CAmeron, M. F., hazarika, M. H., AND Jones, G. H. 1966. Nuclear variation between diploid angiosperms. Nature, 211, 828-830.

ROTHFEls, K., SEXSMith, E., HEIMBURGer, m., AND KRAUSE, M. o. 1966. Chromosome size and DNA content of species of Anemone L. and related genera (Ranum culaceae). Chromosoma, 20, 54-74.

SUNDERLAND, N., AND MCLEISH, J. 1961. Nucleic acid content and concentration in root cells of higher plants. Exp. Cell Res., 24, 541-554.

\section{THE EFFECT OF POPULATION STRUCTURE ON THE SUCCESS OF INSECT INTRODUCTIONS}

\author{
A. M. LUCAS \\ School of Biological Sciences, The Flinders University of \\ South Australia, Bedford Park, South Australia 5042, Australia
}

Received 7.viii.68

\section{INTRODUCTION}

IT would be an advantage to be able to predict the conditions that will give the best chance of success when an insect species is introduced into an area to control a pest. Remington (1968) has produced a model which, he suggests, enables such predictions to be made. However, some inconsistencies appear in his paper.

\section{Remington's model and predictions}

Remington summarises his model of the structure of an insect population as follows:

"... there are two opposite genetic structures and their intermediates.

1. The ecologically marginal portions of the population are small inbred units with high homozygosity and a very low frequency of deleterious 
recessive alleles (i.e. a small "genetic load"). The individuals in these marginal sectors all tend to be closely adapted to one narrow set of environmental parameters.

2. The ecologically central portions of the species are populous, outcrossed units with high heterozygosity and a large genetic load. The individuals in these central sectors tend to be generally adapted to a wide range of microenvironments" (p. 417).

It must be noted that Remington uses " ecologically marginal " to refer to populations near the environmental limits of the species; they are typically minimal in size and often exist at the geographic periphery of the species, but they may be geographically central. "Ecologically central populations", usually at the geographic centre of the species, tend to be "maximal in abundance, stability and panmixis".

The evidence quoted to support this model comes largely from work on Drosophila populations. Dobzhansky et al. (1963), using D. pseudobscurra, Townsend (1952), using D. willistoni, and Alexander (1952), using the $D$. virilis group, have shown that ecologically marginal populations carried smaller percentages of heterozygous genes than did ecologically favourable populations. Most of this work has estimated the proportion of lethals and semilethals in the populations, but some (see Townsend, 1952) has investigated visibly expressed recessives and chromosome inversions as well.

Using this model as his starting point, Remington then discusses the consequences of the introduction of large and small founder populations from ecologically central or marginal source populations. He claims that if the source population is marginal, it makes little difference whether a large or small sample is introduced; in both cases there is " good potential for early survival and evolution soon of (a) new type". But the size of the founder population is expected to produce different results when an ecologically central source population is involved; with few founders he predicts that " early extinction (is) likely", but he expects the introduced population to have a " good potential for early survival, but low potential for the evolution of (a) new type " when many founders are introduced. The model, and its consequences, according to Remington, are summarised in table 1.

\section{Criticisms of Remington's Predictions}

If the model is accepted as sound, it seems that Remington has assumed that the major reason for population extinction upon introduction to a new area will be the effect of the genetic load; founders from marginal populations will have a low genetic load, and so survive, whereas founders from central populations will have a high genetic load, and so be susceptible to extinction unless a large number of founders are introduced. When discussing the control of unwanted introduced insects he does not seem to have taken into account the comment quoted above that " the individuals in these marginal sectors tend to be closely adapted to one narrow set of environmental parameters". One would expect that insects introduced from a marginal population are unlikely to be adapted to their new environment with its different biotic and abiotic factors. Therefore a "good potential for survival" of such introductions would not be expected, even though they may have less genetic load than central populations. The genetic load, 


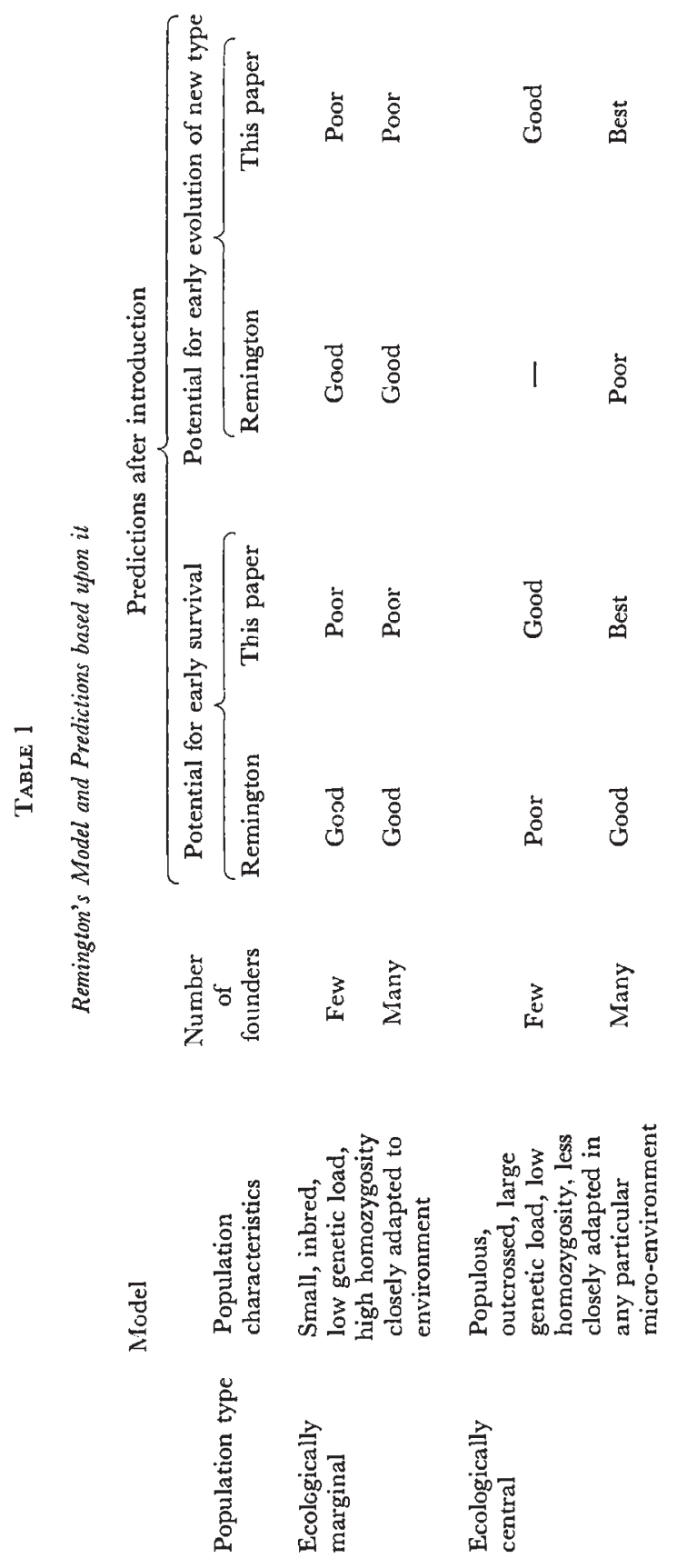


itself, may not be very important in limiting populations, as Turner and Williamson, (1968), point out.

Similarly, because founders from a marginal source population are homozygous for more genes than those from a central population, they are unlikely to have as much potential for the evolution of a new type; there is less variation immediately available for selection to act upon and produce organisms well adapted to the new environment. So, contrary to Remington's prediction, founders from a central population should have more potential for evolution of a new type than those from a marginal source population.

When he gives his " rules of thumb" for successful introduction of beneficial insects Remington seems to have interpreted the genetic model correctly. He advocates the introduction of " a large wild sample from a large, central source population" and warns against "introducing few founders from a large source population or making mass releases from laboratory rearings bred from one or a few individuals collected from a large source population". This procedure will maximise the genetic variability upon which selection can operate to produce a population of organisms well adapted to the new environment. Remington's paper is internally inconsistent here: if he followed his model, summarised in table 1 of this paper, he should have advocated introduction from marginal populations to produce the ideal of an early evolution of a type well adapted to the new environment.

\section{Alternative predictions}

These criticisms may be summarised in the following predictions based upon the same model as Remington's:

1. The best chance of establishment of a population would be when founders come from an ecologically central population.

2. The best chance for the evolution of a new type in the new environment would occur when the founders come from a population that was ecologically central.

The effect of the size of the founder population on initial survival in the new environment is not clear, provided the sample is large enough to ensure near certainty of breeding individuals meeting and mating. But, the larger the founder population from an ecologically central source, the greater will be the chance of including favourable genes in the new gene pool, so one would expect that a large sample from this type of source would have the greatest potential for the evolution of new types. Since homozygosity is assumed, in the model, to be relatively high in populations that are ecologically marginal, the number of founders will make little difference to the low potential for evolution of populations initiated from this type of source.

These predictions, and Remington's, can be tested by examining the records of introductions that have been attempted for two types of information; the genetic changes that have taken place since the introduction, and the type of source population from which the founders came. Satisfactory data of the first type are difficult to obtain, since the genetic constitution of the source population is unlikely to have been recorded at the time of the introduction. One has to compare the present status of the source population and that of the " new " population, and assume that any divergence is due to 
evolution taking place in the new poulation. This is an unsatisfactory assumption, since it neglects the effects of the "founder principle" and of evolution taking place in the source population itself. The effect of the latter can be quite marked, as Mason et al. (1968) have shown.

Information of the second type, if available, is more reliable, since the present status of the source is of no importance. As long as the type of population, ecologically marginal or central, at the time of the introduction is known, the data are useful. In many cases, the satus of the population is likely to remain stable, and comparisons based on present status will be useful.

\section{Tests of the prediction}

One of the " classical " examples of biological control by the introduction of an insect species is the control of the cottony cushion scale, Icerya purchasi, in California by the ladybird beetle Novius (Vedalia) cardinalis introduced

TABLE 2

Insects introduced into Australia to combat prickly-pear. The number of insects introduced is given in parentheses

\begin{tabular}{|c|c|}
\hline $\begin{array}{l}\text { Nature of source } \\
\text { population }\end{array}$ & Established \\
\hline Ecologically central & $\begin{array}{l}\text { Cactoblastis cactorum }(<50) \\
\text { Olycella junctolineela }(100) \\
\text { Moneilema ulkei }(10,000)\end{array}$ \\
\hline $\begin{array}{l}\text { Ecologically } \\
\text { marginal }\end{array}$ & \\
\hline $\begin{array}{l}\text { Insufficient data to } \\
\text { classify }\end{array}$ & $\begin{array}{l}\text { Tucumania tapiacola }(700) \\
\text { Moneilema variolare }(900) \\
\text { Logachirus funestus }(2900) \\
\text { Chelinidea vittiger }(2500) \\
\text { C. tabulata }(1300)\end{array}$ \\
\hline
\end{tabular}

Not established

Cuctoblastis doddi $(>1000)$

Melitara prodenialis $(11,000)$

Melitara sp. $(32,000)$

Melitara dentata $(1000)$

M. doddalis $(13,000)$

In addition, five species of Dactylopius were introduced. Details of the number of founders are not given for these stocks. The special features of this genus are discussed in the text. $D$. opuntiae, $D$. newsteadi, $D$. cylonicas, $D$. species near confusus were all established; $D$. confusus failed to become established in the field. The data for this table are taken from Dodd, (1940).

from Australia. Although the original status of $\mathcal{N}$. cardinalis is not recorded, the species is at present widespread in Australia, (Matheson, personal communication), and can be considered to be ecologically central although the adult, at least, appears to feed only upon $I$. purchasi (French, 1893). The Californian populations were initiated by 139 specimens of the ladybird, a native enemy of the scale in Australia (Elton, 1958).

The other classical case is the control of the prickly pear, Opuntia spp, in Australia. The work leading to its control is well documented, and the data used for the following discussion are drawn from Dodd (1940). These data are summarised in table 2. The insect that produced the best control of the plant was a moth, Cactoblastis cactorum. The Australian populations of the moth are descended from about 1000 eggs laid by moths that emerged from larvae collected in the field in the Argentine where the species was widespread and common at the time of collection. The fecundity data suggest 
that these eggs were obtained from about fifteen females, so the Australian stocks came from less than fifty founder individuals.

Cactoblastis cactorum was one of the eighteen insect species which, after passing stringent host range restriction tests, were introduced into Australia with the aim of establishing them in the field. In most cases, Dodd's data are insufficient to make a decision about the ecological status of the founders. In some measure, all these species were ecologically marginal, in that they had a narrow host range, (only Opuntia spp), but if we consider species able to survive on more than one Opuntia species, and which were common in their country of origin, as ecologically central, we see that two of the five species in this category were not established although many founders were introduced. Two of the three that became established had small $(<150)$ founder populations, while the other was quite large, (in the order of 10,000).

The one species, Melitara sp, that can be classified as ecologically marginal because of its extremely restricted host range was not established, even though 32,500 individuals were introduced. The species was aimed at Opuntia inermis which is " rather closely related to $O$. lindheimeri", one form of which is its normal host plant.

Five of the seven species which cannot be classified with respect to their original ecological status became established after relatively few insects were introduced, but the other two, with 13,000 founders in one case, did not become established.

The Cochineal insects Dactylopius spp are a special case, since there appeared to be "biological forms of the same species possessing marked differences in their capacity to survive on, and to effect injury to, the different kinds of prickly-pear". For example $D$. confusus was shipped from Florida on Opuntia stricta, $O$. dillenii and $O$. polycarpa. All three strains infected Australian $O$. stricta, but that on $O$. dillenii made much more rapid progress on the Australian $O$. stricta than did the material infecting the same species of prickly pear in Florida. In most cases repeated introductions of different strains of the Dactylopius spp were necessary before establishment succeeded. The Dactylopius species appear to be ecologically marginal and repeated trials were needed before a strain adapted to the Australian conditions was found. Four out of five species introduced became established.

\section{Conalusion}

The data presented here, from a limited number of insect introductions, support the predictions of this paper rather than those of Remington. Both Cactoblastis cactorum and Novius (Vedalia) cardinalis were very successfully introduced with a small founder population drawn from populations that appear to have been ecologically central. The one clear case of an introduction from an ecologically marginal population failed to become established even with a large number of founders.

\section{SUMMARY}

1. Remington's (1968) model of the structure of insect populations is described, and the predictions based upon it criticised.

2. Alternate predictions, that most successful introductions will come from diverse ecologically central populations, are presented. 
3. These predictions are tested by examining the history of the introduction of eighteen insects to control prickly pear in Australia, and of the introduction of the ladybird to control scale insects in California. Remington's predictions are not supported.

Acknowledgments.-Miss E. Matheson supplied details of the localities for specimens of Novius cardinalis logded in the National Museum of Victoria. Professor A. M. Clark and Dr N. G. Brink read the typescript.

\title{
REFERENGES
}

ALEXANDER, M. L. 1952. Gene variability in the americana-texana-novomexicana group of Drosophila. Univ. Texas Publ. 5204, 73.

DOBZHANSKY, T., HUNTER, A.s., PAVlovsky, O., SPASSKY, B., AND WALlaCE, B. 1963. Genetics of natural populations. XXXI. Genetics of an isolated marginal population of Drosophila pseudobscurra. Genetics, 48, 91 .

DoDD, A. P. 1940. The Biological Campaign against Prickly-Pear. Commonwealth PricklyPear Board, Brisbane.

FRENCH, C. 1893. A Handbook of the Destructive Insects of Victoria. Part II; Government Printer, Melbourne.

MASON, L. G., EHRLICH, P. R., AND EMMEL, T. C. 1968. The population Biology of the butterfly, Euphydras editha. IV. Phenetics of the Jasper Ridge colony, 1965-66. Evolution, 22, 46. Elton, c. s. 1958. The Ecology of Invasions by Animals and Plants. Methuen, London.

REMrngton, C. L. 1968. The population genetics of insect introduction. Ann. Rev. Entomol., $13,415$.

TOWNSEND, J. I., JR. 1952. Genetics of marginal populations of Drosophila willistoni. Evolution, 6, 428.

TURner, J. R. G., AND williamson, M. H. 1968. Toleration of a Genetic Load. Nature, 218, 5142,700 .

\section{APOSTATIC SELECTION AND POPULATION DENSITY}

\author{
J. J. D. GREENWOOD \\ Department of Zoology, Manchester University *
}

Received 6.xii.68

R. A. FIsHer pointed out in 1930 that in a population in which rare genotypes were at a selective advantage to common ones, simply by virtue of their rarity, a polymorphism would be maintained. Later experiments made by Popham (1941, 1942) upon the predation by Rudd, Scardinius (Leuciscus) eryophthalmus L., on polymorphic populations of the aquatic bug Sigara distincta (Fieb.) showed that the fish tended to take a disproportionately high number of the commoner morphs of the bug. The work of these two authors led to the hypothesis that predators might be responsible for the maintenance of polymorphisms in populations of their prey. Cain and Sheppard (1954) and Haldane (1955) suggested that the widespread polymorphism of shellcolour and pattern in snails of the genus Cepaea (Held.) might be maintained in this way, though they did not suggest that this was likely. The evidence that predators do, indeed, behave so as to tend to maintain polymorphisms in their prey was summarised by Clarke $(1962 a, b)$, who used the term " apostatic" for the first time in this context. Clarke argued that apostatic selection had detectable effects on the polymorphism of Cepaea. However, Carter (1967) has contested Clarke's interpretation of the evidence.

* Present Address: Dept. of Biological Sciences, The University, Dundee. 